\title{
Language Proficiency Development and Study Abroad Experience: $A$ Study on EFL Learners ${ }^{1}$
}

Desarrollo del Dominio del Idioma y la Experiencia de Estudio en el Extranjero: un Estudio sobre Estudiantes de Inglés como Lengua Extranjera

\section{Fatma Kaya ${ }^{2 *}$}

\section{Erzurum Technical University, Turkey}

\footnotetext{
${ }_{1}$ Received: September 9th 2020/Accepted: July 21st 2021

2 fatma.kaya@erzurum.edu.tr
} 


\section{Abstract}

Study abroad experience (SA) has been regarded as one of the best ways to enhance English language proficiency because it offers opportunities for learners to experience the use of English in actual situations. The present research study attempted to explore the language development of a group of EFL learners participating in Erasmus program for SA experience where English is not used as L1. To achieve this, the data were collected through three instruments: Language Contact Profile (LCP), Then and Now Survey, and semi-structured interviews. Fifty-nine students answered LCP and Then and Now Survey and eight students were interviewed. The quantitative result revealed that students experienced greater gains in their oral skills. On the other hand, qualitative results confirm the greater gains in speaking skills with respect to other skills. Moreover, the results highlighted the significance of the learning context and the quality and quantity of interaction for language development.

Key Words: Study abroad; English proficiency; English learners; Learning context; oral skills; interaction

\section{Resumen}

La experiencia de estudiar en el extranjero (EE) ha sido catalogada como una de las mejores formas de mejorar la competencia en inglés porque esta ofrece oportunidades a los aprendices de experimentar el uso de la lengua en situaciones reales. El presente estudio de investigación intentó explorar el desarrollo de la lengua en un grupo de estudiantes de inglés como lengua extranjera en el programa Erasmus para la experiencia EE en dónde el inglés no es usado como lengua primaria o L1. Para alcanzar esto, los datos se recolectaron a través de tres instrumentos: Perfil de Contacto de Idioma (PCI), Encuesta de antes y ahora, y entrevistas semiestructuradas. Cincuenta y nueve estudiantes respondieron el PCI y las encuestas; y ocho estudiantes fueron entrevistados. Los resultados cuantitativos revelaron que los estudiantes experimentaron mayores ganancias en sus habilidades orales. Por otro lado, los resultados cualitativos confirman dichas ganancias en habilidades de habla con respecto a otras habilidades. Además, los resultados resaltan el significado del contexto de aprendizaje y la calidad y cantidad de interacción para el desarrollo del lenguaje.

Palabras clave: estudiar en el extranjero; competencia en inglés; aprendices de inglés; contexto de aprendizaje; habilidades de habla; interacción

\section{Resumo}

A experiência de estudar no estrangeiro (EE) foi catalogada como uma das melhores formas de melhorar a competência em inglês, porque esta oferece oportunidades aos aprendizes de experimentar o uso da língua em situações reais. O presente estudo tentou explorar o desenvolvimento da língua em um grupo de estudantes de inglês como língua estrangeira no programa Erasmus para a experiência $\mathrm{EE}$, onde o inglês não é utilizado como língua primária ou L1. Para alcançar isso, os dados foram coletados através de três instrumentos: Perfil de Contato 
de Idioma (PCI), Enquete de antes e agora, e entrevistas semiestruturadas. Cinquenta e nove estudantes responderam o PCI e as enquetes; e oito estudantes foram entrevistados. Os resultados quantitativos revelaram que os estudantes experimentaram maiores aproveitamentos em suas habilidades orais. Por outro lado, os resultados qualitativos confirmam tais aproveitamentos em habilidades de fala com relação a outras habilidades. Além disso, os resultados ressaltam o significado do contexto de aprendizado e a qualidade e quantidade de interação para o desenvolvimento da linguagem.

Palavras chave: estudar no estrangeiro; competência em inglês; aprendizes de inglês; contexto de aprendizado; habilidades de fala; interação 


\section{Introduction}

earning context plays a significant role in the development of foreign language and affects the degree of language acquisition and the gained result (Sanz \& Grey, 2015 cited in Leonard \& Shea, 2017). Therefore, "One of the most important variables that affects the nature and the extent to which learners acquire an L2 is the context of learning" (Collentine, 2009, p. 218 cited in Llanes, 2011, p. 189) because the level and type of language input provided by SA, the chances created to engage in interaction, and the target language exposure display differences ( Amuzie \& Winke, 2009). Thus, most SA research has focused on the nature of study abroad experience and has attempted to discover the determinants which may promote language enhancement (Dewey, 2007) because different variables such as personal, academic, linguistic, and cultural affects the degree of SA experience that students benefit from (Cadd, 2012).

In fact, study abroad programs aim to serve for two general purposes: improving and enhancing L2 proficiency and developing cultural sensitivity (Baker'Smemoe, Dewey, Bown \& Martinsen, 2014). In line with the crucial role of SA experience as recognized one of the best ways to enhance language proficiency, there has been a steadily growing interest on the research exploring the benefits of SA programs on language development, though studies sometimes present inconsistent results that do not align with each other. However, while dealing with the effects of SA on language learning, we need to support the premise that language learning context be the prerequisite focus that needs to be taken into consideration if the underlying factors that comprise the effects of SA experience on learners' language gains are sought to explore. This gap may be explained by various factors such as frequency, intensity, quality, and quantity of interaction in the target language context.

Relevant literature on SA experience emphasizes that interaction with local English speakers and developing social networks in the target language are one of the most important factors to improve language proficiency of learners and higher L2 contact leads to greater language gains (Llanes, Tragant \& Serrano, 2012) because, in contrast to classroom environments, sojourns create settings which can provide useful chances for learners to interact in the target language (Schwieter, Jackson \& Ferreira, 2018). However, as Martinsen (2010) says interaction with native speakers does not always lead to enhancement of language proficiency and more studies are required to evaluate the relationship between social networks and the development of speaking skills. In fact, the significance of SA experience for language enhancement should not lead to the assumption that the classroom environment does not contribute to the language development; however, actual environments may create a pressure on students to use language to communicate in actual conditions. 
Given the potential effect of SA experience on students' language proficiency, a thorough understanding of the process, particularly in terms of students who experience their sojourn in countries where English is not L1 and reflections of these students upon their sojourns is needed. Hence, this study attempts to investigate language development of Turkish students participating in Erasmus program utilizing both qualitative and quantitative data to have a deeper insight into the process.

\section{Literature Review}

There has been a growing interest in the studies exploring the effects of SA experience on language proficiency and students' attitudes towards the target language in terms of different dimension of SA experience and different language skills. Although learning context has been determined as one of the key factors leading to success regardless of the explored language gains, not all SA experiences cover the same duration and the duration of SA programs has determined the language gains, particularly gains in specific L2 areas. Some scholars have addressed the length of SA program on language gains, particularly exploring whether short term SA experience could enhance language proficiency (Evans \& Fisher, 2005; Martinsen, 2010; Llanes \& Munõz, 2009). For example, in the study conducted by Martinsen (2010), the effects of a period of 6 weeks SA experience on oral skills were explored and it was found that this short term experience showed significant changes in learners' oral skills; however, there were also learners with no change or even decrease in their oral skills. The researcher attributes this issue to the measurement problem because it is challenging to measure the development of language skills over a short time and this measurement problem of study abroad experience research was also confirmed by Dewey (2007). Moreover, an interesting implication made by Martinsen (2010) is the probability that interacting with native speakers during SA experience does not always lead to the development of oral skills and, thus, the frequency and quality of interaction should be the foci of further research. On the other hand, further evidence of the effectiveness of short duration on the enhancement of proficiency comes from Llanes and Munõz (2009), who considered that even a period of 3-4 weeks of SA experience showed considerable gains in language areas such as listening comprehension, oral fluency, and accuracy.

In fact, it may be advocated that the chances of being exposed to L2 interaction created by SA environment are not similar in every context and not all L2 learners prefer to get involved in interaction in the target language (Montero, 2019) and "mere exposure to the context is not enough, and SA participants need to take the opportunities which the context offers for interaction and sociocultural learning" (Sánchez-Hernández \& Alcón-Soler, 2019, p. 14). In their studies, Leonard and Shea (2017) investigated native English speakers who spend one semester in Argentina. The 
main focus of their study is to explore changes in various dimensions of complexity, accuracy, and fluency (CAF) over a period of 3 months sojourn and whether any relationship is available between these changes and linguistic knowledge and processing rate. As a result, they revealed that learners experienced development in syntactic complexity, accuracy and fluency. Moreover, they added that in long term, three dimensions of speaking improve and when the learner has achieved a definite degree of fluency that also leads to definite degree of accuracy and lexical complexity.

However, as most researchers emphasized that learners with higher proficiency levels before study abroad experience also experienced greater gains in accuracy and syntactic and lexical complexity during the process. Interestingly, researchers point out that learners with lower levels show greater improvements when compared to learners with more advanced levels during study abroad experience (Martinsen, 2010). Thus, to explain this conclusion, Dewey (2007) elucidated the possible ceiling effect in measures utilized in study abroad research because most of the used measures are thought to be insufficient to evaluate the gains of advanced-level learners and the language gains advanced learners experience are not easy to quantify (Llanes \& Munõz, 2009).

Another point deserving attention is the outcomes gained at the end of the process. Researchers emphasize that study abroad experience does not always guarantee effective language development and learning (Martinsen, 2010; Yang \& Kim, 2011); however, this experience seems to facilitate language acquisition. For example, Dewey (2007) elucidates the facilitator effect of SA experience on vocabulary acquisition; however; he does not also ignore the significant gains, which can be obtained at home. In fact, the distinguishing point between classroom and study abroad context is that target language context creates a relatively unconscious focus to master language while classroom context offers practice on grammar and vocabulary knowledge (DeKeyse, 1991 cited in Kim \& Cha, 2017) and the intensity of language exposure (Serrano, Llanes \& Tragant, 2016). However, different benefits may come from both of the contexts in various fields of language. For example, SA context seems to favor oral lexical richness while at Home $(\mathrm{AH})$ context leads to better receptive knowledge of grammar (Serrano et al., 2016). The notion that SA significantly favors oral proficiency also was confirmed by the studies of Llanes et al., (2012) and Jochum (2014). For example, Montero (2019) explored whether SA learners outgained at home learners in terms of the development of effective communicative strategies. The noteworthy point addressed in the results is that not all SA learners make effective use of L2 communication opportunities and their counterparts at home can also benefit from these opportunities if similar settings are reproduced. The most important contribution of the study may be explained by the explicit call for further need to motivate and encourage learners to benefit SA experience at maximum level by actively participating in each actual communication settings. 
Moreover, studies have also focused on the effect of SA experience on self-efficacy of learners (e.g., Cubillos \& Ilvento, 2013; Kim \&Cha, 2017; Petersdotter, Niehoff \& Freund, 2017). For example, in their studies, Kim and Cha (2017) examined what factors compose self-efficacy and tried to explore the relationship between English proficiency, abroad experience and English self-efficacy. Moreover, they investigated the optimal period of study abroad experience for the self-efficacy improvement. As a result, they concluded that English proficiency and abroad experience have the exploratory value for self-efficacy with the dominant effect of English proficiency on self-efficacy. However, what the researchers emphasize is the need to study the factors jointly instead of treating factors alone. On the one hand, the optimal period for the development of self-efficacy was recognized from four to six months.

On the other hand, further evidence of effective outcomes of SA experience has been also displayed from pragmatic or sociolinguistic perspectives (e.g., Taguchi, 2008; Shively, 2011; Taguchi, 2011; Alcón-Soler, 2015; Sánchez-Hernández \& AlcónSoler, 2019; Devlin, 2018; Ren, 2019). For example, Sánchez-Hernández and AlcónSoler (2019) examined the enhancement of pragmatic competence of the sojourn of a group of Brazilian students during their first semester of study in a US university. The main foci of the study are two: recognition of pragmatic routines, and whether intensity of interaction and participants' sociocultural adaptation to the SA context are the determinants of documented pragmatic development. As a result, it was revealed that a semester-long sojourn improves the recognition of pragmatic routines and intensity of interaction and sociocultural adaptation determine the documented pragmatic gains.

Likewise, Alcón- Soler (2015) conducted a more specific study dealing with the impact of pragmatic instruction and the duration of SA on e-mail request mitigators of teenagers creating an experimental and a control group consisting of 30 participants in each group in England. It was concluded that SA has shown an immediate effect on request of mitigators which was not sustained in the long term. However, these two studies have established their research in Anglophone contexts which may result in an enriched environment where learners may easily engage in actual communication settings through intensive and frequent interaction with native speakers of English. However, when it comes to analyze the effect of SA on pragmatic competence, in settings where English is used as a Lingua Franca, it may be hard to know to what extent pragmatic competence may be enriched.

Although the aforementioned studies have mostly focused on revealing the effects of sojourn on linguistic or pragmatic gains, researchers have also documented the effect of SA experience on participants' beliefs and perceptions on the effectiveness of this experience (e.g. Asoodar, Atei \& Bate, 2017). For example, Amuzie and Winke (2009) examined the relationship among learners' beliefs, study abroad, and duration of the SA exploring the beliefs held by two groups of students who have been to the 
USA for more than six months and those who had been to the USA longer. They found that SA experience led both groups to believe that they should be responsible to create occasions to engage in L2 and instead of the classroom environment, success is more related to their attempts. Moreover, they declared that as a result of the changes in their beliefs through the SA program, learners who studied longer abroad developed greater learner autonomy than those who experienced abroad less.

Another controversial issue is the optimal time in which SA experience may have an impact to affect the enhancement of language proficiency. In fact, what makes the contraction about the effectiveness of the short- term SA is whether this experience creates sustainable linguistic, motivational, or personal beliefs because research draws inconsistent conclusions in terms of linguistic and nonlinguistic benefits (Allen, 2010). Different studies have yielded various outcomes. A stay abroad of even 3- 4 weeks was observed to significantly affects language gains and learners are claimed to benefit from 1-week SA experience (Llanes \& Munõz, 2009). Numerous studies have established their research on the short term and long term SA research such as evaluating the impact of short-term SA experience on learners' attitudes towards Spanish (Artamonova, 2017), whether short-terms experience makes difference (Llanes \& Muñoz, 2009) or assessing the effect of SA on transformative learning comparing six weeks programs (Walters, Charles \& Bingham, 2017). Regarding the optimal period for effective SA, the studies have drawn the conclusion that sojourns from 3 to 12 months lead to the maximum gains (Dwyer, 2004; Koester, 1985 cited in Allen, 2010).

In contrast to the ample studies on SA experience, in Turkish context more studies are required that explore the impact of SA experience on the enhancement of language development particularly asking participants through diverse data collection tools about their experiences as sojourners. Moreover, exploring the language development of EFL learners who spend their SA experience in countries where English is not the L1 also deserves attention. Given the importance of SA context on the enhancement of language proficiency, the current study seeks to explore the changes in learners' proficiency during their sojourn in countries where English is not L1 addressing the following research questions:

1. How much time do students spend using English and Turkish during their sojourn?

2. Is there any statistically significant difference between learners pre- and postself-assessment in terms of language proficiency?

3. What changes do students experience in their language proficiency before and after their study abroad experience and how did this experience influence their attitudes towards the English language?

4. What difficulties, if any, participants experience during their sojourn? 


\section{Methodology}

This study aimed to gather data about the language development of the participants as they engaged in SA experience and to achieve this, both qualitative and quantitative data were utilized because research into SA experience has been often criticized due to lack of multiple data sources. Therefore, the present study employed two types of data to draw conclusions recognizing the potential benefits of combining both qualitative and quantitative measures to understand the language development experienced during participants' sojourn. The quantitative data were complemented with qualitative sources. The participants answered the relevant questionnaire with a 5 Likert-type scale and completed Language Contact Profile. Moreover, for a comprehensive analysis, semi-structured interviews were conducted 


\section{Participants}

Table 1 shows the detailed demographic characteristics of the students in the sample.

Table 1. Demographic Information of the Participants

\begin{tabular}{|c|c|c|}
\hline Background Information & $\mathbf{N}$ & $\%$ \\
\hline \multicolumn{3}{|l|}{ Faculty } \\
\hline Faculty of Arts & 17 & 28.8 \\
\hline Faculty of Engineering & 10 & 16.9 \\
\hline Faculty of Education & 9 & 15.2 \\
\hline Faculty of Law & 7 & 11.8 \\
\hline Faculty of Economics and Administrative Sciences & 5 & 8.4 \\
\hline Others & 11 & 15.2 \\
\hline \multicolumn{3}{|l|}{ Age } \\
\hline $17-20$ & 8 & 13.6 \\
\hline $21-24$ & 40 & 67.8 \\
\hline 25-29 & 11 & 18.6 \\
\hline \multicolumn{3}{|l|}{ Gender } \\
\hline Male & 38 & 64.4 \\
\hline Female & 21 & 35.6 \\
\hline \multicolumn{3}{|c|}{ ELF communities visited through the Erasmus Program } \\
\hline Poland & 17 & 28.8 \\
\hline Germany & 9 & 15.2 \\
\hline Spain & 6 & 10.1 \\
\hline Hungary & 6 & 10.1 \\
\hline Romania & 6 & 10.1 \\
\hline Others & 15 & 23.7 \\
\hline \multicolumn{3}{|l|}{ Duration of Study Abroad Experience } \\
\hline $1-3$ months & 4 & 6.8 \\
\hline 4-6 months & 53 & 89.8 \\
\hline 7-12 months & 2 & 3.4 \\
\hline
\end{tabular}


The participants of the current study were 59 Erasmus exchange students who aimed to study in various EFL contexts during the 2017-2018 Fall and Spring semesters and 2018-2019 Fall semester. The sample of the study was composed of students who were studying at a large Turkish state university, and these students were diverse in terms of their majors and the countries they visited through the Erasmus exchange program. The average age of students was between 18 and 29 years old and all of the participants were native speakers of Turkish. The official Erasmus exchange program lasted 3 to 12 months.

\section{Instruments}

In the current study, the quantitative instrument consisted of a Then and Now Survey and Language Contact Profile. The information obtained from these measures was complemented with qualitative data derived from semi-structured interviews with eight participants.

\section{Then and Now Survey}

Then and now survey (Dewey, Bown \& Eggett, 2012) was used to capture the participants' beliefs before and after the SA experience. The purpose for using Then and Now survey is to explore the possible changes in students' language proficiency. In the recent years, post + retrospective pre-test method, which includes the learners' evaluation of their abilities only at the end of their study period, has replaced the traditional pre-test/ post-test design (Dewey et al., 2012). According to Hill and Bertz (2005), "If the aim is to understand how participants feel about program effectiveness and their personal growth or skill acquisition, the retrospective test provides a more direct assessment of these factors" (p.514). In case of being unfamiliar with tasks, learners may overestimate or underestimate their skills before the experience (Dewey et al., 2012). In Then and Now survey, each statement appears twice, once asking about the degree of difficulty what the participants had believed while at home and what they currently believed after their sojourn. The items sought responses with 5 - point Likert-type scale to elicit the self-perception of progress. The participants were asked to rate their abilities to achieve the given tasks using the scale that includes: not at all; with great difficulty; with some difficulty; easily; quite easily.

\section{Language Contact Profile}

The Language Contact Profile (LCP) created by Freed, Dewey and Segalowitz and Halter (2004) was used to determine the quantity of participants' interaction with 
English speakers during their sojourn. LCP was used to assess the amount of interaction in various contexts such as in classroom, with friends and with strangers (Hernández, Alcón-Soler, 2018). For each question in LCP, participants were asked to provide the approximate number of hours per week and per day they involved in various activities. It was expected that the approximate periods reported by participants would provide valuable information about the input learners receive and output learners produce during their sojourn (Llanes \& Munõz, 2009)

\section{Semi-Structured Interviews}

Volunteer students participated in semi-structured interviews and the participants were asked questions aiming to elicit underlying factors that may explain the effectiveness of study abroad experience. The interviews were conducted in Turkish to make participants easily express their ideas and feelings. Interviews were one-on-one, had a duration of 15-30 minutes, and were audio-taped and then transcribed.

\section{Data Analysis}

The data consisted of two types, the quantitative data from the Likert-scale type of Then and Now survey which enabled learners to make a self-assessment on their language development and LCP and the qualitative data obtained from the interviews. The main purpose of collecting and analyzing quantitative data was to provide a general framework for the participants' responses which would be used to explore the differences between changes in language proficiency held before and after SA experience. The second purpose, through qualitative findings, was to examine the underlying detailed reasons for, if any, enhancement of language proficiency and attitudes towards English took place.

The quantitative data were analyzed through SPSS 21.0 and for the statistical analysis, t-test was employed to find whether there was any statistical difference between pre and post beliefs. The data were submitted to t-test to examine the changes between what the participants believed in their home country (prior to SA experience) and what they believed after their sojourn about their language proficiency. On the other hand, the qualitative data were analyzed through content analysis. Firstly, the codes were formed out of answers and after defining the codes; the researcher combined them into categories and themes. Moreover, to establish the reliability of coding, the researchers studied with an invited coder who has experience in content analysis. 


\section{Results}

\section{The Results of Quantitative Analysis}

A paired sample t-test was conducted to examine if there was any change in the students' language proficiency across pre- and post- study abroad. The first research question addresses the amount of time students spent using English and Turkish during their sojourn. Figure 1 displays the number of hours students reported speaking, reading and writing, and listening to English and Turkish during the SA experience.

Figure 1. Reported Overall Number of Hours Spent per Week Using English and Turkish

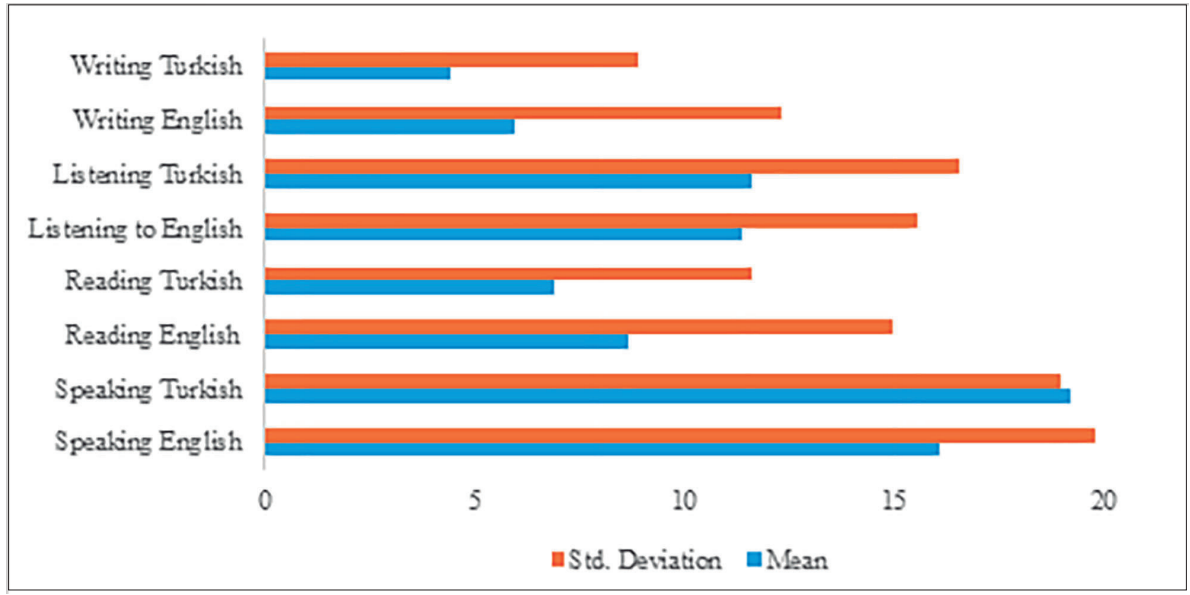

As it can be seen in Figure 1, students reported spending most of their time on speaking Turkish and the secondly English; however, the difference between speaking English and Turkish is not high. The time spent on reading and writing in English is higher than the time spent on Turkish; however, the time spent on listening to Turkish and English seems approximately the same.

Figure 2 shows the ten most frequent activities reported in the LCP giving an overview of the specific ways learners used English and Turkish. The activities are sorted from lowest (least number of hours) to the highest (most hours). 
Figure 2. Number of Hours Spent in Ten Frequent LCP Activities (sorted from lowest (least number of hours) to the highest (most hours)

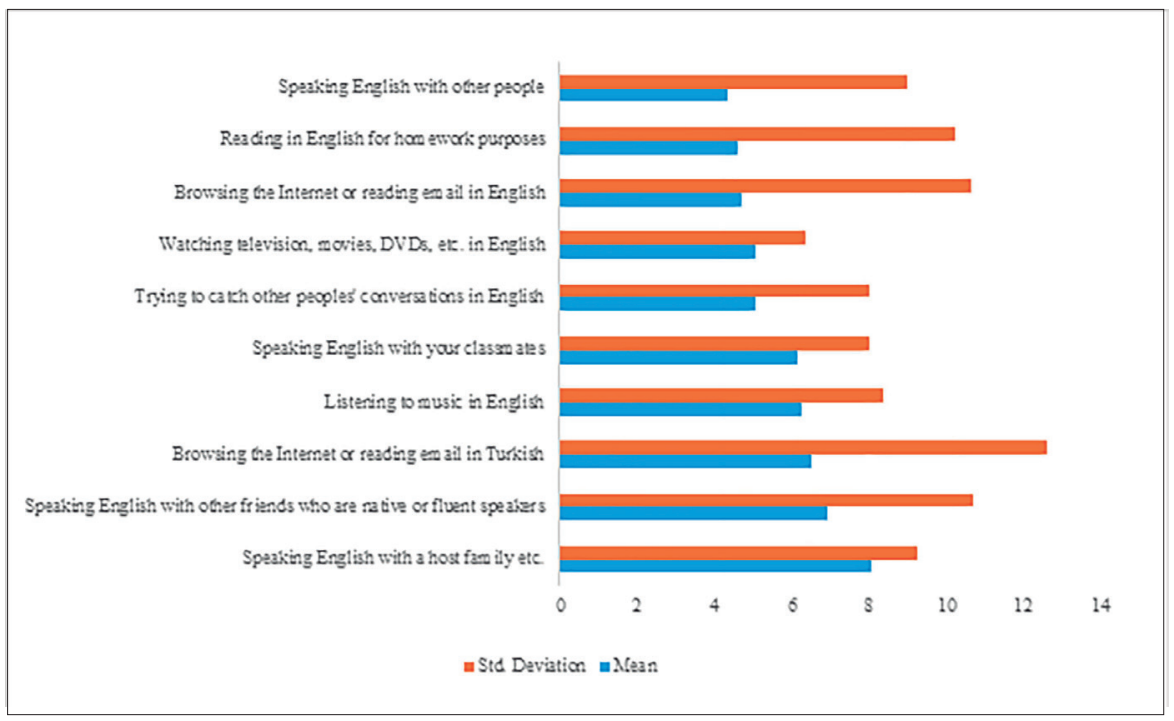

As shown in figure 2, students spent most of their time using English as they were engaged in conversations with the speakers around their environment, particularly within their settlements. Then following speaking, they reported to spend the most time reading in English for academic purposes. On the other hand, among the ten most frequent LCP activities, they spent less time using English to speak with other people.

Table 2 displays the results of the pre- and post-self-evaluation of speaking abilities obtained using the t-test. The results were sorted from the highest mean change to the lowest. As seen in table, there are statistically significant differences in every aspect of Then and Now self-assessment. The result of the statistical analysis has displayed that SA experience has positive effects on students' L2 skills leading to significant gains in the case of oral production. They seem to have developed their language proficiency and have experienced significant gains. As shown in Table 2, students benefited SA experience in terms of various gains. SA experience has developed their oral language skills such as giving information about themselves, surviving in an English speaking environment, engaging in daily conversations or talking about political and abstract issues. Hence, these quantitative findings confirm that engaging in actual situations have contributed to their language proficiency. 
Table 2. T- Test Statistics for Then-Now Self-Assessment (Pre-/Post-Comparison)

\begin{tabular}{|c|c|c|c|c|c|}
\hline Items & $\begin{array}{l}\text { Mean } \\
\text { Change }\end{array}$ & $\begin{array}{l}\text { Standard } \\
\text { Deviation }\end{array}$ & $\begin{array}{c}\mathrm{t} \\
\text { Statistic }\end{array}$ & df & Probability \\
\hline $\begin{array}{l}\text { Speak in English without having } \\
\text { to substitute English words or } \\
\text { guess excessively how to say } \\
\text { something. }\end{array}$ & 5.440 & 4.857 & 8.603 & 58 & 0.000 \\
\hline $\begin{array}{l}\text { Deal with complications in } \\
\text { situations (e.g., situations } \\
\text { where the other person in the } \\
\text { conversation doesn't say what } \\
\text { you expect or behaves outside of } \\
\text { your expectations). }\end{array}$ & 5.372 & 5.037 & 8.193 & 58 & 0.000 \\
\hline $\begin{array}{l}\text { Speak fluently without } \\
\text { interruption. }\end{array}$ & 5.322 & 4.284 & 9.540 & 58 & 0.000 \\
\hline $\begin{array}{l}\text { Use a wide variety of vocabulary } \\
\text { to express your thoughts without } \\
\text { getting hung up on words (i.e., } \\
\text { not being able to find the word } \\
\text { you need to say what you want } \\
\text { to say) }\end{array}$ & 5.016 & 4.431 & 8.696 & 58 & 0.000 \\
\hline $\begin{array}{l}\text { Describe your present job, } \\
\text { studies (classes, major, etc.), } \\
\text { and professional and academic } \\
\text { interests. }\end{array}$ & 4.966 & 4.574 & 8.338 & 58 & 0.000 \\
\hline $\begin{array}{l}\text { Describe college life to another } \\
\text { person in detail. }\end{array}$ & 4.949 & 5.224 & 7.277 & 58 & 0.000 \\
\hline $\begin{array}{l}\text { Satisfy simple personal needs and } \\
\text { social demands to survive in an } \\
\text { English-speaking setting }\end{array}$ & 4.949 & 4.632 & 8.206 & 58 & 0.000 \\
\hline $\begin{array}{l}\text { Participate actively in } \\
\text { conversations in most informal } \\
\text { and some formal settings on } \\
\text { topics of personal and public } \\
\text { interest }\end{array}$ & 4.915 & 6.251 & 6.039 & 58 & 0.000 \\
\hline $\begin{array}{l}\text { Describe events and objects in } \\
\text { the past, present, and future }\end{array}$ & 4.813 & 4.443 & 8.322 & 58 & 0.000 \\
\hline $\begin{array}{l}\text { Speak without producing errors } \\
\text { that might disturb or distract a } \\
\text { English speaking listener. }\end{array}$ & 4.745 & 4.655 & 7.830 & 58 & 0.000 \\
\hline $\begin{array}{l}\text { Obtain and give information by } \\
\text { asking and answering questions }\end{array}$ & 4.508 & 5.170 & 6.697 & 58 & 0.000 \\
\hline
\end{tabular}




\begin{tabular}{|l|c|c|c|c|c|}
\hline $\begin{array}{l}\text { State and support with examples } \\
\text { opinions about controversial } \\
\text { topics. }\end{array}$ & 4.471 & 4.409 & 7.440 & 58 & 0.000 \\
\hline $\begin{array}{l}\text { Respond to simple questions } \\
\text { on the most common aspects of } \\
\text { daily life }\end{array}$ & 4.305 & 5.302 & 6.237 & 58 & 0.000 \\
\hline $\begin{array}{l}\text { Speak about abstract topics, } \\
\text { connecting ideas logically and } \\
\text { smoothly }\end{array}$ & 3.932 & 3.929 & 7.686 & 58 & 0.000 \\
\hline $\begin{array}{l}\text { Tell what you plan to be doing 5 } \\
\text { or more years from now }\end{array}$ & 3.915 & 4.691 & 6.410 & 58 & 0.000 \\
\hline $\begin{array}{l}\text { Express nearly any idea you } \\
\text { could express in your native } \\
\text { language. }\end{array}$ & 3.610 & 3.439 & 8.063 & 58 & 0.000 \\
\hline $\begin{array}{l}\text { Talk about current political issues } \\
\text { in English. }\end{array}$ & 3.593 & 3.815 & 7.234 & 58 & 0.000 \\
\hline $\begin{array}{l}\text { Give simple biographical } \\
\text { information about self (name, } \\
\text { age, composition of family, etc.). }\end{array}$ & 3.423 & 4.713 & 5.580 & 58 & 0.000 \\
\hline Speculate and present hypotheses & 3.389 & 3.363 & 7.742 & 58 & 0.000 \\
\hline $\begin{array}{l}\text { Deal with linguistically } \\
\text { unfamiliar situations (situations } \\
\text { never before encountered in } \\
\text { English) }\end{array}$ & 3.349 & 5.093 & 5.955 & 58 & 0.000 \\
\hline $\begin{array}{l}\text { Say simple greetings, courtesy } \\
\text { phrases like "thank you," and use } \\
\text { appropriate language when taking } \\
\text { leave. }\end{array}$ & 2.694 & 4.259 & 4.859 & 58 & 0.000 \\
\hline
\end{tabular}

\section{The Results of Qualitative Analysis}

To gain a more comprehensive understanding, answers by eight participants in semi-structured interviews were analyzed through the content analysis. The results obtained from the content analysis are displayed in tables that include codes, categories, and themes.

Table 3 shows the changes in attitudes students have experienced towards English during their sojourn. The first term concerns the changes in participants' attitudes towards English after the sojourn. The category deals with language-related factors. As shown in Table 3, after the SA experience, learners generally positively commented about the changes they felt and almost all of the participants referred to language-related changes such as more interest in English, less fear of making mistakes, and motivation 
to improve English. Regarding the changes in attitudes, one of the participants provided a general comment stating her wish to improve English proficiency and to acquire fluent speaking She mentioned her desire as follows:

"I want to improve my English until I can speak English like my mother language because it has no border, you know, too." (Participant 1)

Table 3. Theme for Changes in Attitudes towards English

\begin{tabular}{|l|l|}
\hline \multicolumn{2}{|c|}{ THEME 1. Changes in Attitudes towards English } \\
\hline Categories & \multicolumn{1}{c|}{ Codes } \\
\hline Category 1. Language Related Changes & Intelligibility rather than accuracy \\
& Noticing the gap between theory and practice \\
& Motivated to improve English \\
& Desire to be a fluent speaker \\
& More interest in English \\
& Less fear of making mistakes \\
& Using English for communicative purposes \\
& More tolerance for grammar mistakes \\
\hline
\end{tabular}

The second theme, changes in language proficiency, is related to the differences or improvement participants have experienced after their sojourns. Table 4 displayed these changes in language skills.

As observed in Table 4, the first category is about the changes in speaking skill. The participants in this study generally shared the belief that significant changes appeared in their speaking skill as given in the first category. The following excerpt is what one of the participants provided as a comment on the change in terms of speaking in his proficiency:

"My English was good before abroad. However, I was not good at practice. That is to say, I learned English but I did not have anybody to speak, chat and have dialogue in my environment. During this 4,5-month period, I practiced heavily particularly in terms of speaking. I can make sentences easily while speaking. That is, I do not think. In case of an unknown question, I can answer quickly." (Participant 8)

For the second and third category, participants mentioned that they acquired more listening comprehension and for writing skills, they gained the ability to write spontaneously. Moreover, another category is about the lexis particularly, the daily language use participants have experienced. 
Table 4. Theme for Changes in Language Proficiency

\begin{tabular}{|c|l|}
\hline \multicolumn{2}{|c|}{ THEME 2. Changes in Language Proficiency } \\
\hline Categories & \multicolumn{1}{|c|}{ Codes } \\
\hline Category 1. Speaking & Fluency \\
& Better pronunciation \\
& Speaking English with a local accent \\
& $\begin{array}{l}\text { Spontaneous speech } \\
\text { Quick answers }\end{array}$ \\
\hline Category 2. Writing & Easier communication \\
\hline Ctaegory3. Listening & Writing without planning/thinking \\
\hline Category 4. Lexis & More comprehension \\
\hline Category 6. Others & Learning terms \\
& Learning idioms \\
& Learning phrases/collocations \\
& Vocabulary use in actual context \\
\hline & No change in grammar knowledge \\
& Deterioration of grammar \\
\hline & Thinking in English \\
\hline
\end{tabular}

As can be seen in Table 4, issues that were regarded as gains by the participants were basically lexical gains. The fourth category includes lexical gains ranging from learning idioms to the vocabulary use in actual context. Considering this issue, one of the participants uttered:

"One day, it was raining, it was raining heavily. We were walking and trying to have a conversation. One of my friends said that it is raining like cats and dogs. I was surprised whether I got it right. Then I asked what she meant exactly. She explained. I have learned it and I liked it so much." (Participant 8)

However, for the grammar category, participants did not refer to a common change. While uttering the effective changes in their language proficiency as a whole, they generally mentioned no significant change or even deterioration for grammar knowledge. For example, one of the participants remarked: 
"Before going abroad through Erasmus program, my grammar was very good; however, I cannot explain, after Erasmus, my grammar began to deteriorate because I tended to use spoken language there." (Participant 3 )

Another issue that is pointed out is the changes in participants' translation skill. One of the participants translated a book from English into Turkish during her sojourn. Another participant mentioned that the SA experience provided the ability of thinking in English. In general, participants have experienced that sojourn had significant contribution for them.

Table 5. Theme for Challenges

\begin{tabular}{|c|c|}
\hline \multicolumn{2}{|c|}{ THEME 3. Challenges } \\
\hline Categories & Codes \\
\hline Category 1. Lexical Challenges & Phrasal verbs \\
& Phrases \\
\hline Category 2. Linguistic Challenges & Various accents \\
& Insufficient Language proficiency \\
\hline Category 3. Social Challenges & Local people not knowing English \\
& Cultural problems/diet habits \\
\hline
\end{tabular}

Theme 3 is about the challenges that participants encountered during their sojourn and Table 5 displays these challenges. Actually, most of the issues which were regarded as challenging were related to the lexical problems. As shown in table 5, lexical challenges constitute the first category and issues ranging from phrasal verbs to phrases are the most frequently mentioned problems encountered during the sojourn. One of the participants' comments supports this notion:

"While speaking to the students, we sometimes could not express ourselves because we knew the words they did not know, they knew the words we did not know. However, we did not experience this problem with professors because their language proficiency is above ours and they could get what we mean even though we could not express ourselves." (Participant 7)

Another challenge mentioned is the linguistic challenges. Some participants pointed out that they had friends from different parts of the world during their sojourn, therefore; their accents sometimes led to problems in terms of comprehension. The following excerpt approves this notion:

"I have experienced difficulty due to the accents of some countries. Particularly, Indian and Spanish speakers' accents were challenging." (Participant 6) 
Social challenges are also another issue uttered during the interviews. In accordance with the social structure of the visited countries, if the local people do not have English proficiency, this leads participants to make great effort to maintain their daily life. In countries such as Hungary, local people do not know English and this leads to the problems for the participants as they try to maintain their daily lives.

\section{Discussion}

The present study attempted to shed light on the language development of EFL learners during their sojourn. Therefore, the results of the current study constitute an attempt to provide an overview of the effect of SA experience on English language proficiency. According to the findings of LCP, which aims to determine the approximate time spent for different activities during sojourn, students spoke Turkish most frequently, however, the percentage is also very high and near to Turkish in English use. In terms of time spent for specific activities, the highest specific area of language is speaking English with people around them. The higher use of Turkish by students may be attributed to the various factors such as a tendency to spend time with friends from the same country due to affective reasons, not desiring to create a chance for effective communication in English and the conditions of the countries visited through the Erasmus program. The results derived from interviews also supported the findings of LCP in terms of the visited countries because students indicated that local people's English proficiency is not high and this led to challenges for them. This finding corroborates Amuzie and Winke's (2009) study, which revealed that leaners show a tendency for clustering with friends from the same country not only in the class but also outside of the class. Additionally, some participants could not be exposed to English because the local people did not use English for communication particularly in countries such as Hungary and Poland. In line with the current results, Kaypak and Ortaçtepe (2014) in their study also came to a similar conclusion that students in Slovenia and Poland could not experience English language enhancement because English is not frequently used by the local people in these countries. On the other hand, Llanes et al (2012) contradicts this conclusion and adds that learning context is not the only factor that determines the L2 gains because somewhat, individual differences play a significant role in the L2 proficiency enhancement.

However, regarding the results obtained from then and now survey, the results of the study revealed that there are differences between students' pre- and post- proficiency levels in English regarding speaking skill. The quantitative findings indicate that there are statistically significant changes in learners' language proficiency. These results show that most of the students experienced improvements in their oral language skills over the period of their sojourn which is in line with existing literature that corroborates positive effects of SA on L2 oral proficiency (Llanes et al., 2012; Dewey, Belnap, \& Hillstrom, 2013; Leonard \&Shea, 2017). 
The interviews conducted with students actually confirm the quantitative findings because the wide range of gains indicated by the participant refers to oral skills. Given the quantitative results which shows that that SA experience has positively affected language skills of students such as fluency, enlarging vocabulary knowledge, participating actively in conversation and speaking spontaneously, it is seen that qualitative findings drawn from students' interviews align with these results because students have uttered important improvement in their language proficiency including quickly answering questions, improving vocabulary knowledge, development of pronunciation and communicating easily. Moreover, what the qualitative data reveal is that participants acquire self-confidence in terms of using oral skills and this led to a decrease in their fears of making mistakes during the communication in English. This finding is in line with previous research which has indicated that learners of English benefit SA experience mainly in oral skills (Freed et al., 2004; Segalowitz \& Freed, 2004; Llanes \& Munóz, 2009; Martinsen, 2010; Llanes, 2012). On the other hand, according to the reflections of students in our study, SA experience does not seem to favor written skills. Freed, So and Lazar (2003) and Llanes et al,. (2012) and Llanes (2010) also revealed similar results indicating that SA experience is more effective for oral skills than written skills. However, explaining the less development of writing skill is a complex issue and deserves more attention to clarify the underlying factors. One of these factors may be related to the major of the students because during the interviews it was observed that students majoring in social sciences tend to need writing during their sojourn more than students majoring in physical sciences.

Moreover, as the result of SA experience revealed, the participants have reshaped their perception of using language because they stated less fear of making mistakes during their interaction in the target language, which means they tend to have a shift from accuracy to fluency which was also advocated by the study of Kaypak and Ortaçtepe (2014) who concluded a similar result. In fact, interviewed participants in our study mostly refer to gains related to speaking skills rather than writing, reading or listening. This emphasis may be attributed to their motivation for traveling abroad because they perceive SA experience as a chance to be involved in interaction with English speakers and develop their speaking proficiency. Therefore, all foci of students are related to the enhancement of their oral skills.

Additionally, what deserves particular attention regarding the current findings is that the target country visited for SA experience plays a crucial role in explaining the language gains. The quality and quantity of interaction for the communicative use of English provided by the target context substantially determines the degree of language gains. In our study, students studied in European countries and some of these countries present only restricted exposure to English in their social and academic lives. Moreover, the intensity of English language use changed according to the context. In general, the result obtained by Martinsen (2010), which falls contradictory with the existing literature (Hernández \& Alcón-Soler, 2019) concluded that on contrary to the 
common assumption, the interaction was not a significant predictor of the changes in oral skills. However, he added that only partial support is available for this result and the nature of the interaction, rather than quantity of interaction, may determine the effectiveness of learning.

Ultimately, findings from the current study contribute to the effectiveness of SA experience on language enhancement. Our findings are also of significance because instead of focusing on context as in the most of the research such as USA or UK where learners have the chance of full exposure to English, our study focuses on the contexts where English is the common language used for communication because most of the EFL learners do not have the chance to visit these countries. Therefore, it provides useful results to explore the language -related contribution of visiting countries where English is Lingua Franca, not the L1.

\section{Conclusion}

This study has addressed the effect of SA experience on English language enhancement. Both quantitative and qualitative data were gathered. The quantitative results showed that participants experienced language gains when compared to their pre- and post- self-assessment. On the other hand, qualitative data illustrated the gains in terms of four language skills and challenges they encountered during the process.

Findings from the study suggest that SA experience seems to favor language proficiency. However, the target context where learners experienced SA is of significance because the interviews indicate that the quality and quantity of interaction determine the degree of gains. The more the interaction is, the greater the gains are. On the one hand, it needs to be emphasized that in addition to the chances presented by the target context, learners should try individually, as Sánchez-Hernández and Alcón-Soler (2019) suggest pure exposure is not adequate and the learners need to maximize the chances of engaging in communication.

Finally, this study highlights that language learning cannot actually take place without using language for communication in actual settings and SA experience is one of the best ways to achieve learning. However, reliable measurement tools should be employed to reveal the changes and improvement in learners' language proficiency levels because measuring the language gains in terms of different skills is a complex issue. In line with this assumption, the effectiveness of SA experience, particularly in a context where English is not the L1, need to be thoroughly explored to provide researchers with more information about how this process influences language proficiency and what changes take place under what conditions in the target language. 


\section{References}

Alcón-Soler, E. (2015). Pragmatic learning and study abroad: Effects of instruction and length of stay. System, 48, 62-74. https://doi.org/10.1016/j.system.2014.09.005

Allen, H. W. (2010). What shapes short-term study. Journal of Studies in International Education, 14(5), 452-470. https://doi.org/10.1177/1028315309334739

Amuzie, G. L., \& Winke, P. (2009). Changes in language learning beliefs as a result of study abroad. System, 37, 366-379. https://doi.org/10.1016/j.system.2009.02.011

Artamonova, T. (2017). Assessing the impact of short-term study abroad [Unpublished Doctor of Philosophy Dissertation]. School of Languages and Cultures West Lafayette, Indiana.

Asoodar, M., Atai, M., \& Baten, L. (2017). Successful erasmus experience: Analysing perceptions before, during and after Erasmus. Journal of Research in International Education, 16(1), 80-97. https://doi.org/10.1177/1475240917704331

Baker - Smemoe, W., Dewey, D., Bown, J., \&Martinsen, R. (2014). Variables affecting L2 gains during study abroad. Foreign Language Annals, 47(3), 475-486. https:// doi.org/10.1111/flan.12093

Cadd, M. (2012). Encouraging students to engage with native speakers during study abroad. Foreign Language Annals, 45(2), 229-245. https://doi.org/10.1111/j.19449720.2012.01188.x

Cubillos, J. H., \& Ilvento, T. (2013). The impact of study abroad on students' self $\nabla$ efficacy perceptions. Foreign Language Annals, 4, 494-511. https://doi.org/10.1111/ flan. 12002

Devlin, A. M. (2018). The interaction between duration of study abroad, diversity of loci of learning and sociopragmatic variation patterns: A comparative study. Journal of Pragmatics, 146, 121-136. https://doi.org/10.1016/j.pragma.2018.08.007

Dewey, D. P. (2007). Language learning during study abroad: What we know and what we have yet to learn. Japanese Language and Literature, 41(2), 245-269. https://doi. org/10.2307/30198037

Dewey, D. P., Belnap, K., \& Hillstrom, R. (2013). Social network development, language Use, and language acquisition during study abroad: Arabic language learners' perspectives. Frontiers: The Interdisciplinary Journal of Study Abroad, 22, 84-110. https://frontiersjournal.org/wp-content/uploads/2015/09/DEWEY-BELKNAPHILLSTROM-FrontiersXXII. Social Network Development Language Useand Language Acquisition During Study Abroad.pdf 
Dewey, D. P., Bown, J., \& Egget, D. (2012). Japanese language proficiency, social networking, and language use during study abroad: Learners' perspectives. Proficiency, Social Networking, and Language Use, 68(2), 111-137. https://doi. org/10.3138/cmlr.68.2.111

Evans, M., \& Fisher, L. (2005). Measuring gains in pupils' foreign language competence as a result of participation in a school exchange visit: The case of Y9 pupils at three comprehensive schools in the UK. Language Teaching Research, 9(2), 173-192. https://doi.org/10.1191/1362168805lr162oa

Freed, B., So, S., \& Lazar, N. (2003). Language learning abroad: How do gains in written fluency compare with gains in oral fluency in French as a second language? ADFL Bulletin, 34(3), 34-40. https://doi.org/10.1191/13621688051r162oa

Freed, B., Dewey, D., Segalowitz, N., \& Halter, R. (2004). The Language Contact Profile. Studies in Second Language Acquisition, 26(2), 349-356. https://doi.org/10.1017/ S027226310426209X

Hill, L.G., \& Betz, D.L. (2005). Revisiting the retrospective pretest. American Journal of Evaluation, 26(4), 501-517. http://dx.doi.org/10.1177/1098214005281356.

Jochum, C. J. (2014). Measuring the effects of a semester abroad on students' oral proficiency gains: A comparison of at-home and study abroad. Frontiers: The Interdisciplinary Journal of Study Abroad, XXIV, 94-104. https://frontiersjournal. org/wp-content/uploads/2015/09/JOCHUM-FrontiersXXIV-MeasuringtheEffects ofaSemesterAbroadonStudentsOralProficiencyGains.pdf

Kaypak, E., \& Ortaçtepe, D. (2014). Language learner beliefs and study abroad: A study on English as a lingua Franca (ELF). System, 42, 355-367. http://dx.doi. org/10.1016/j.system.2014.01.005

Kim, H.-I., \& Cha, K.-A. (2017). Effects of experience abroad and language proficiency on self-efficacy beliefs in language learning. Psychological Reports, 120(4), 670-694. https://doi.org/10.1177/0033294117697088

Leonard, K. R., \& Shea, C. E. (2017). L2 Speaking development during study abroad: fluency, accuracy, complexity, and underlying cognitive factors. The Modern Language Journal, 101(1), 79-193. https://doi.org/10.1111/modl.12382

Llanes, À. \& Munõz, C. (2009). A short stay abroad: Does it make a difference?. System, 37(3), 353-365. https://doi.org/10.1016/j.system.2009.03.001

Llanes, À. (2011). The many faces of study abroad: an update on the research on L2 gains emerged during a study abroad experience. International Journal of Multilingualism, 8(3), 189-215. https://doi.org/10.1080/14790718.2010.550297 
Llanes, À., Tragant, E., \& Serrano, R. (2012). The role of individual differences in a study abroad experience: the case of Erasmus students. International Journal of Multilingualism, 9(3), 318-342. https://doi.org/10.1080/14790718.2011.620614

Martinsen, R. A. (2010). Short-Term study abroad: Predicting changes in oral skills. Foreign Language Annals, 43(3), 504-530. https://doi.org/10.1111/j.19449720.2010.01095.x

Montero, L. (2019). Developing effective L2 communication strategies. The Language Learning Journal, 45(5), 642-652. https://doi.org/10.1080/09571736.2017.1357744

Petersdotter, L., Niehoff, E., \& Freund, P. (2017). International experience makes a difference: Effects of studying abroad on students' self-efficacy. Personality and Individual Differences, 17, 174-178. http://dx.doi.org/10.1016/j.paid.2016.11.040

Ren, W. (2019). Pragmatic development of Chinese during study abroad: A crosssectional study of learner requests. Journal of Pragmatics, 146, 137-149. https:// doi.org/10.1016/j.pragma.2019.01.017

Sánchez-Hernández, A., \& Alcón-Soler, E. (2019). Pragmatic gains in the study abroad context: Learners' experiences and recognition of pragmatic routines. Journal of Pragmatics, 146, 54-71. https://doi.org/10.1016/j.pragma.2018.08.006

Schwieter, J. W., Jackson, J., \& Ferreira, A. (2018). When 'domestic' and 'international' students study abroad: reflections on language learning, contact, and culture. International Journal of Bilingual Education and Bilingualism, 1-14. https://doi.org /10.1080/13670050.2018.1447545

Segalowitz, N., \& Freed, B. (2004). Context, contact, and cognition in oral fluency acquisition. SSLA, 26, 173-199. https://doi.org/10.1017/S0272263104262027

Serrano, R., Llanes, A. \& Tragant, E. (2016). Examining L2 development in two shortterm intensive programs for teenagers: Study abroad vs. "at home”. System, 57, 4354. https://doi.org/10.1177/1362168816639757

Shively, R. L. (2011). L2 pragmatic development in study abroad: A longitudinal study of Spanish service encounters. Journal of Pragmatics, 43, 1818-1835. https://doi. org/10.1016/j.pragma.2010.10.030

Taguchi, N. (2008). Cognition, language contact, and the development of pragmatic comprehension in a study-abroad context. Language Learning, 58(1), 33-71. https://doi.org/10.1111/j.1467-9922.2011.00633.x

Taguchi, N. (2011). The effect of L2 proficiency and study-abroad experience on pragmatic comprehension. Language Learning, 61(3), 904-939. https://doi. org/10.1111/j.1467-9922.2011.00633.x 
Walters, C., Charles, J. \& Bingham, S. (2017). Impact of short-term study abroad experiences on transformative learning: A comparison of programs at 6weeks. Journal of Transformative Education, 15(2), 103-121. https://doi. org/10.1177/1541344616670034

Yang, J.-S., \& Kim, T.-Y. (2011). Sociocultural analysis of second language learner beliefs: A qualitative case study of two study-abroad ESL learners. System, 39, 325334. https://doi.org/10.1016/j.system.2011.07.005

\section{Author}

${ }^{\star}$ Fatma Kaya is an English lecturer and works at Erzurum Technical University, School of Foreign Languages in Turkey. She is a PhD candidate at Atatürk University, School of Education, Department of English Teaching. Her research interests are English academic writing and educational research.

ORCID: https://orcid.org/0000-0002-7140-1915

How to reference this article: Kaya, F. (2021) Language Proficiency Development and Study Abroad Experience: A Study On EFL Learners. GIST - Education and Learning Research Journal, 23, 33-58. https://doi.org/10.26817/16925777.943 